\title{
EKSISTENSI SUKU DAYAK SEBERUANG MENGHADAPI TEKANAN MODERNISASI MELALUI RITUAL GAWAI DAYAK
}

\author{
Septian Peterianus ${ }^{1}$, Mastiah $^{2}$ \\ ${ }^{1,2}$ STKIP Melawi \\ Jln. RSUD Melawi, Nanga Pinoh, Kabupaten Melawi, Kalimantan Barat 79672 \\ e-mail: speterianus@gmail.com, mastiah2011@gmail.com
}

\begin{abstract}
Abstrak: Tujuan akhir dari penelitian ini adalah untuk mengetahui dan mendeskripsikan bagaimana eksistensi Suku Dayak Seberuang dalam menghadapi tekanan modernisasi melalui Ritual Dayak. Penelitian ini adalah penelitian kualitatif. Penggunaan metode kualitatif dikarenakan oleh permasalahan belum jelas, holistik, komplek, dinamis serta penuh makna. Hasil wawancara dengan beberapa tokoh adat di Dusun Pau Tengah Desa Nanga Pau menunjukkan bahwa Gawai Dayak Suku Seberuang mampu bertahan menghadapi tekanan modernisasi. Hal tersebut ditunjukkan dengan beberapa hal seperti: Pertama, masih ada Suku Dayak yang menguasai dan mengerti tata cara melaksanakan ritual menggunakan bahasa Dayak Seberuang. Kedua, seluruh elemen masyarakat antusias mengikuti prosesi ritual adat dari awal sampai berakhir. Ketiga, peralatan yang digunakan tetap tradisional, menunjukkan bahwa tradisi asli suku Dayak Seberuang masih tetap dipertahankan.

Kata Kunci: Eksistensi, Suku Dayak Seberuang, Modernisasi, Ritual Gawai Dayak.
\end{abstract}

$\mathrm{M}$

embicarakan suku Dayak tentu tidak bisa lepas dari keindahan

Pulau Kalimantan. Riwut dalam bukunya Kalimantan Membangun Alam dan Kebudayaan [1], mengatakan bahwa Pulau Kalimantan memiliki segudang pesona dan kearifan lokal yang tidak dimiliki wilayah lainnya. Pulau ini dihuni oleh berbagai suku dengan keberagaman budaya dan adat masing-masing. [2]

Ukur dalam buku Tantang Jawab Suku Dayak sebagaimana yang dikutip oleh Lontaan dalam buku Sejarah Hukum
Adat dan Adat Istiadat Kalimantan Barat [3] mengatakan bahwa suku Dayak terbagi ke dalam enam rumpun besar yang disebut "STAMMENRAS". Dari enam rumpun besar ini dibagi lagi ke dalam sub suku kecil berjumlah 405 sub suku Dayak. Banyaknya jumlah sub suku Dayak ini menunjukkan betapa kayanya kearifan lokal yang dimiliki Pulau Kalimantan. [4]

Kekayaan alam dan budaya yang dimiliki Pulau Kalimantan sudah sepatutnya menjadi tanggung jawab bersama dalam menjaga eksistensinya 


\section{Bestari: Jurnal Pendidikan dan Kebudayaan}

Volume 1 Nomor 2 Oktober 2020

dimata masyarakat Indonesia maupun dunia Internasional. Akan tetapi saat ini, berbagai keindahan yang dimiliki Pulau Kalimantan sepertinya semakin hilang ditelan arus modernisasi. Wajar saja jika muncul kekhawatiran bahwa generasi muda yang seharusnya mewarisi kekayaan kearifan lokal ini tidak akan bisa lagi mengenal kampung halamannya.

Berangkat dari uraian di atas, Dayak Seberuang merupakan salah satu sub suku Dayak yang masuk dalam rumpun Ibanic (memiliki persamaan bahasa, namun ada beberapa perbedaan), yang banyak bermukim di wilayah-wilayah Kalimantan Barat hingga ke daerah Sarawak Malaysia. Hingga saat ini eksistensi Dayak Seberuang masih terus ditunjukkan dengan selalu mempertahankan budaya dan kearifan lokal yang mereka miliki, salah satunya adalah melaksanakan ritual Gawai Dayak.

Gawai Dayak suku Seberuang menjadi ritual tahunan yang selalu dilaksankan dengan cara tradisional. Ritual ini juga dianggap sebagai upacara sakral penuh mistis dan hanya orang-orang tertentu sajalah (ketua adat) yang diperbolehkan untuk memimpin kegiatan ritual gawai ini. Tidak jauh berbeda dengan ritual Gawai Dayak umumnya, kegiatan ini dilaksanakan sebagai ungkapan rasa syukur atas hasil panen yang melimpah dari sang pencipta. Sebelum ritual berlangsung, ketua adat akan menyiapkan perlengkapan untuk ritual seperti: tikar, daun pisang, nasi, kepala babi, tempat sesaji dari bambu dan masih banyak lagi sebagai syarat untuk melaksanakannya.[5]

Bertolak dari uraian di atas, penelitian dengan judul "Eksistensi Dayak Seberuang Menghadapi Tekanan Modernisasi melalui Ritual Gawai Dayak" menjadi kajian menarik untuk diteliti dalam penelitian ini. Hal ini mengingat bahwa belum banyak literasi maupun penelitian yang menjelaskan secara kongkret tentang suku Dayak Seberuang maupun dinamika yang terjadi di dalamnya, secara khusus di Melawi.

Veth (2012) dalam buku berjudul “Borneo's Westerafdeeling: Geographisch, Statistisch, Historisch" 1854 [6] yang telah diterjemahkan ke dalam bahasa Indonesia oleh P. Yeri Veth menguraikan bahwa orang-orang Dayak adalah penduduk asli yang mendiami Pulau Borneo (Kalimantan). Menurut Veth pola kehidupan orang-orang Dayak zaman dahulu adalah nomaden dan menyebar hingga ke wilayah-wilayah pedalaman.

Hasil penelitian Veth juga menunjukkan bahwa sebagian besar dari orang-orang Dayak yang tinggal di Pulau 


\section{Bestari: Jurnal Pendidikan dan Kebudayaan}

Volume 1 Nomor 2 Oktober 2020

Kalimantan lebih memilih untuk bertempat tinggal di daerah pinggiran sungai. Hal ini disebabkan oleh selain sungai dipakai sebagai jalur transportasi, tinggal di daerah pinggiran sungai juga membuat orang-orang Dayak dapat dengan mudah memanfaatkan sungai sebagai sumber mata pencarian bagi orang-orang Dayak yang bekerja sebagai nelayan.

Selain Veth, Enthoven (1905), dalam buku berjudul Bijdragen Tot De Geographie van

Borneo's Wester-Afdeeeling [7] yang telah diterjemahkan ke dalam bahasa Indonesia oleh P.Yeri, Enthoven memiliki pandangan yang tidak jauh berbeda dengan Veth yakni untuk melihat bagaimana sejarah dan geografis Pulau Kalimantan Barat menurut perspektif peneliti Barat.

Menurut Anouk Fienieg dalam Bullein 377 yang berjudul The History of Sintang [5], mengemukakan bahwa orang-orang Dayak merupakan keturunan dari ras Austronesia yang datang dari dataran Asia Tenggara. Orang-orang Austronesia ini awal mulanya menempuh perjalanan menyusuri wilayah Taiwan lalu menyebrang ke wilayah Filipina hingga menuju Borneo. Hal inilah yang meyakini penelitian Anoug bahwa Austronesia adalah nenek moyang suku Dayak.
Bertolak dari uraian di atas, tampak jelas bahwa belum banyak kajian maupun data penelitian yang membahas secara khusus tentang suku Dayak Seberuang. Kalaupun ada kajian tentang Dayak Seberuang lebih banyak ditemukan dalam bentuk makalah dan tulisan-tulisan dalam media internet. Oleh karena itu, penelitian kualitatif ini dimaksudkan untuk mengetahui dan menggali lebih dalam mengenai eksistensi suku Dayak Seberuang di Melawi yang mampu bertahan menghadapi tekanan modernisasi melalui ritual Gawai Dayak.

Dayak Seberuang masuk dalam rumpun Dayak Ibanic. Rumpun Ibanic atau yang biasa dikenal dengan nama Iban sendiri terdiri dari berbagai sub suku Dayak. Loontaan mencatat bahwa ada 11 sub suku yang masuk ke dalam rumpun Dayak Iban, salah satunya adalah suku Seberuang. Adapun beberapa ciri atau sistem Suku Dayak Seberuang dapat dilihat dari penggunaan bahasa, kesenian/budaya, mata pencarian, dan kepercayaan. Dalam hal bahasa, suku Dayak Seberuang berkomunikasi menggunakan bahasa Seberuang misalnya makan $=$ makai, mandi $=$ manik, mau $\mathrm{ke}$ mana $=$ kak kini. Orang Seberuang memanggil sebutan kaum laki-laki dengan 


\section{Bestari: Jurnal Pendidikan dan Kebudayaan}

Volume 1 Nomor 2 Oktober 2020

sebutan "Mih" dan perempuan dengan sebutan "Dik".

Gawai Dayak Suku Seberuang pada dasarnya merupakan peristiwa budaya yang secara rutin selalu dilaksanakan setiap tahunnya. Dalam kegiatan inti Gawai Dayak Suku Seberuang selalu hal pertama yang dilakukan adalah nyangahathn (pembacaan mantra oleh ketua adat). Namun demikian, selain pembacaan mantra juga ditampilkan pula berbagai bentuk kegiatan budaya seperti: Upacara adat, permainan tradisional dan berbagai macam bentuk kerajianan yang memiliki nuansa tradisional [6].

Perjalanan sejarahnya, Gawai Dayak memang bukanlah peristiwa budaya yang murni tradisional, hal ini bisa dilihat dari tempat pelaksanaan maupun isinya. Istilah Gawai Dayak sendiri sebenarnya merupakan perkembangan lebih lanjut dari kegiatan penyelenggaraan kesenian Dayak yang pertama kali dilakukan pada tahun 1986 oleh Seketariat Bersama Kesenian Dayak (Sekberkesda).

Berkembangnya kegiatan Gawai Dayak memang erat hubungannya dengan semangat untuk mengungkapkan rasa syukur kepada Jubata ${ }^{1}$ yang telah memberikan limpahan rezeki melalui

\footnotetext{
${ }^{1}$ Jubata dalam bahasa Dayak memiliki arti yang maha kuasa (Tuhan)
}

panen padi yang melimpah. Upacara memperingati panen raya ini diperingati oleh suku Dayak dengan nama yang berbeda-beda. Orang Dayak Hulu misalnya menyebut ritual ini dengan nama "Gawai", di Kabupaten Sambas dan Bengkayang disebut dengan nama "Maka Dio”, orang Dayak Kayaan di kampung Mendalam Kapuas Hulu menyebutnya dengan istilah "Dange".

Secara khusus suku Dayak Seberuang menyebut ritual ini dengan nama Gawai Dayak yang memiliki makna tidak jauh berbeda dengan suku Dayak lainnya, yaitu untuk menunjukkan ungkapan rasa syukur masyarakat Dayak Seberuang kepada sang pencipta atas hasil panen padi yang melimpah.

Penelitian dengan judul Eksistensi Suku Dayak Seberuang Menghadapi Tekanan Modernisasi melalui Ritual Gawai Dayak ini akan menggunakan teori eksistensi. Kata eksistensi berasal dari kata eks (keluar) dan sistensi, yang diturunkan dari kata kerja sisto (berdiri, menempatkan). Kata eksistensi diartikan bahwa manusia berdiri sebagai diri sendiri dengan keluar dari dirinya. Manusia sadar bahwa dirinya ada [7].

Menurut Loren Bagus dalam Kamus Filsafat menjelaskan bahwa (1996: 183), eksistensi berasal dari kata existence 


\section{Bestari: Jurnal Pendidikan dan Kebudayaan}

Volume 1 Nomor 2 Oktober 2020

yang berasal dari Bahasa Latin existere yang berarti muncul, ada, timbul, atau memiliki keberadaan aktual [8]. Kamus Bahasa Indonesia sendiri mendefinisikan eksistensi sama dengan keberadaan. Dengan demikian maka artinya eksistensi terkait dengan keberadaan fisik dan fungsi yang melekat dalam dirinya.

Eksistensialisme secara etimologi yakni berasal dari kata eksistensi, dari bahasa latin existere yang berarti muncul, ada, timbul, memilih keberadaan aktual. Adapun eksistensialisme sendiri adalah gerakan filsafat yang menentang esensialisme, pusat perhatiannya adalah situasi manusia.

Bertolak dari uraian di atas, penelitian dengan judul: Eksistensi Suku Dayak Seberuang Menghadapi Tekanan Modernisasi melalui Ritual Gawai Dayak ini memang dirasa tepat menggunakan teori eksistensi. Teori eksistensi digunakan untuk melihat bagaimana eksistensi suku Dayak Seberuang dapat bertahan melawan arus modernisasi yang berkembang sangat cepat di era modern seperti saat ini.

\section{METODE}

Pada penelitian yang mengambil judul: Eksistensi Suku Dayak Seberuang Menghadapi Tekanan Modernisasi melalui Ritual Gawai Dayak ini peneliti menggunakan metode penelitian kualitatif. Adapun alasan peneliti menggunakan metode kualitatif adalah menyangkut persoalan permasalahan yang ditemukan sangat kompleks sehingga tidak dimungkinkan untuk melakukan penelitian kuantitatif. Dengan demikian, tidak dimungkinkan data pada situasi sosial tersebut dijaring menggunakan instrumen test, maupun kuesioner.

Selain itu, peneliti melalui penelitian ini berusaha untuk memahami situasi sosial yang terjadi secara mendalam dengan cara menemukan pola, hipotesis dan teori. Hal ini sejalan dengan pendapat Sugiono dalam bukunya berjudul: Metode Penelitian Pendidikan Pendekatan Kuantitatif Kualitatif dan R\&D yang mengatakan bahwa umumnya penggunaan metode kualitatif karena permasalahan belum jelas, holistik, komplek, dinamis, dan penuh makna sehingga jenis penelitian ini tidak mungkin bisa dilakukan menggunakan metode kuantitatif [9].

\section{HASIL DAN PEMBAHASAN}

Berdasarkan hasil penelitian di Dusun Pau Tengah Desa Nanga Pau, dengan melakukan wawancara bersama tokoh-tokoh adat Suku Dayak Seberuang yang melaksanakan Ritual Gawai Dayak di desa tersebut, menunjukkan bahwa Gawai 


\section{Bestari: Jurnal Pendidikan dan Kebudayaan}

Volume 1 Nomor 2 Oktober 2020

Dayak merupakan salah satu wujud dari eksistensi suku Dayak Seberuang dalam mempertahankan tradisi nenek moyang yang telah dilaksanakan secara turun temurun. Kegiatan rutin ini selalu dilaksanakan setiap tahun antara bulan Mei, Juni atau Juli. ${ }^{2}$ Dengan melaksanakan ritual Gawai Dayak secara rutin menunjukkan bahwa suku Dayak Seberuang tidak melupakan adat serta tradisi leluhur mereka.

Hasil wawancara dengan tokoh-tokoh adat Dayak Seberuang juga menunjukkan bahwa Gawai Dayak mampu bertahan menghadapi tekanan modernisasi. Hal tersebut ditunjukkan dengan masih adanya orang-orang Dayak Seberuang yang menguasai tata cara melakukan ritual menggunakan bahasa Dayak Seberuang. Sekalipun kegiatan ini dianggap sangat tradisional karena menggunakan peralatan seadanya namun antusias masyarakat dalam menyaksikan ritual Gawai Dayak sangatlah tinggi. Kegiatan ini menunjukkan

\footnotetext{
${ }^{2}$ Pelaksanaan Gawai Dayak di Dusun Pau Tengah Desa Nanga Pau dilaksanakan antara bulan Mei, Juni atau Juli. Awalnya kegiatan ini dilakukan setelah masa panen padi selesai antara bulan Mei dan Juli. Namun dalam perkembangan selanjutnya kegiatan ini juga sangat bergantung pada anggaran yang dimiliki Desa Nanga Pau, sebab dalam pelaksanaannya setelah selesai ritual akan ditambah dengan kegiatan lainnya seperti: Bernyanyi bersama, menari dan bersih-bersih desa. Kegiatan ini bisa berlangsung sampai tiga hari lamanya.
}

bahwa generasi Dayak Seberuang masih sangat menjunjung tinggi nilai-nilai budaya yang mereka miliki.

Gawai Dayak dalam sejarahnya merupakan kegiatan yang sudah berlangsung sejak lama yang dijalankan secara turun temurun oleh nenek moyang suku Dayak, dan hingga saat ini tradisi ini diwariskan kepada generasi suku Dayak Kalimantan. Awalnya acara ini dilaksanakan sebagai bentuk ucapan rasa syukur masyarakat Dayak pada roh nenek moyang mereka yang telah memberikan berkat melimpah pada hasil pertanian orang-orang Dayak. Hasil panen padi yang melimpah dalam pandangan suku Dayak tidak lepas dari peran serta para leluhur yang telah memberkati tanah hutan untuk berladang (Kuma). ${ }^{3}$

Pada tahapan selanjutnya, Gawai Dayak berkembang tidak lagi semata-mata sebagai wadah bagi masyarakat Suku Dayak dalam mensyukuri anugrah tuhan yang melimpah dalam hal pertanian, namun lebih dari itu semua Gawai Dayak dimaknai sebagai salah satu identitas dan jati diri suku Dayak dalam

\footnotetext{
${ }^{3}$ Suku Dayak Seberuang menyebut ladang dengan dua istilah nama yaitu: Buma dan Kuma. Keduanya sama-sama memiliki makna berladang. Masyarakat Dayak Seberuang dalam Buma juga mengandalkan sistem berpindah tempat karena mereka tidak menggunakan pupuk kimia dan pestisida lainnya.
} 


\section{Bestari: Jurnal Pendidikan dan Kebudayaan}

Volume 1 Nomor 2 Oktober 2020

mempertahankan eksistensinya di tengah-tengah perkembangan zaman yang semakin modern. Salah satu contohnya adalah Ritual Gawai Dayak suku Seberuang di Desa Nanga Pau, Kecamatan Belimbing, Kabupaten Melawi, Provinsi Kalimantan Barat.

Secara umum, Gawai Dayak memiliki makna filosofis yang dalam bagi masyarakat Dayak di wilayah Kalimantan, secara khusus Dayak Seberuang yang ada di Kabupaten Melawi. Oleh karena itu, dalam pelaksanaannya, kegiatan ini juga dianggap sebagai salah satu kegiatan sakral dan dianggap mistis baik itu oleh masyarakat Seberuang sendiri maupun masyarakat luar yang menyaksikan kegiatan ini. Tempat untuk melaksanakan kegiatan inipun tidak boleh sembarangan, arus dilaksanakan di rumah panjang (Rumah Betang). ${ }^{4}$

Saat akan melaksanakan Ritual Gawai Dayak terlebih dahulu segala keperluan untuk ritual disiapkan oleh ketua adat yang akan memimpin prosesi ritual. Semua syarat untuk ritual dipersiapkan sendiri oleh ketua adat yang dibantu oleh tokoh-tokoh masyarakat Desa Nanga Pau lainnya yang mengerti tentang bagaimana

\footnotetext{
4 Dalam bahasa Suku Dayak Seberuang Rumah Betang disebut dengan istilah Rumah Panyai.
}

cara menyiapkan sesajiannya. Adapun bahan-bahan yang disiapkan untuk ritual adalah: Kemenyan, Beras Kuning, Darah Ayam Jantan, Kepala Babi, Nasi Pulut, ${ }^{5}$ Nasi Putih, daun pisang, tikar, tuak, telur ayam, dan berbagai macam jenis sayuran hasil dari Buma untuk ritual Umpan Pentik. $^{6}$

"Umpan Pentik" menjadi simbol untuk memulai ritual Gawai Dayak. Setelah semua bahan atau sesajian untuk ritual tersedia maka ketua adat akan memimpin ritual pembacaan mantra menggunakan bahasa Dayak Seberuang. Menggunakan bahasa Dayak Seberuang pemimpin ritual mencoba untuk berkomunikasi dengan roh para leluhur dengan tujuan meminta izin melaksanakan Gawai Dayak di wilayah tersebut. Selain itu, pembacaan mantra juga bertujuan untuk menyampaikan ucapan syukur kepada leluhur yang telah memberkati hasil panen masyarakat Dayak Seberuang. ${ }^{7}$

Selanjutnya setelah ritual Gawai Dayak selesai dilaksanakan, secara resmi

\footnotetext{
5 Pulut merupakan jenis beras ketan yang dalam bahasa Dayak Seberuang dikenal dengan nama Pulut.

${ }^{6}$ Umpan Pentik adalah prosesi sakral yang harus dilakukan sebelum memulai Ritual Gawai Dayak. Pentik merupakah patung dari ukiran kayu belian yang diberi makan atau sesaji.

7 Wawancara dengan Ketua Temenggung Desa Nanga Pau Bapak Selili.
} 


\section{Bestari: Jurnal Pendidikan dan Kebudayaan}

Volume 1 Nomor 2 Oktober 2020

kegiatan gawai akan dibuka oleh ketua adat. Namun demikian, sebelum memulai kegiatan selanjutnya terlebih dahulu ketua adat mengajak seluruh masyarakat untuk menikmati sesajian yang telah disiapkan. ${ }^{8}$ Dengan berakhirnya ritual pembacaan mantra maka Gawai Dayak secara resmi dibuka dan berlangsung selama beberapa hari.

\section{DAFTAR PUSTAKA}

[1] Riwut, T. (2007). Kalimantan Membangun Alam dan Kebudayaan. Jogjakarta: Galang Press. Bagian Layout.

[2] Lontaan, J. U. (1975). Sejarah Hukum Adat dan Adat Istiadat Kalimantan Barat. Jakarta: BUMIRESTU

[3] Veth, P. J. (2012). Borneo Bagian Barat: Geografis, Statistis, Historis. Terjemahan. P. Yeri, OFM. Cap. Jilid 1. Pontianak: Institut Dayakologi.

[4] Enthoven, J. J. K. (1905). (Bijdragen Tot De Geographie Van Borneo's Wester-Afdeeling). Dialihbahasakan oleh: P. Yeri, OFM. Cap. Sejarah dan Geografi Daerah Sungai

\footnotetext{
${ }^{8}$ Sesajian "Umpan Pentik" yang telah disiapkan setelah ritual selesai harus dinikmati oleh masyarakat yang hadir. Akan tetapi tidak dihabiskan, namun hanya mencicipi sedikit seperti: minum tuak dan makan pulut.
}

Kapuas Kalimantan Barat.

Pontianak: Institut Dayakologi, 2013

[5] Fienieg, A. (2011). The History of Sintang. Tropenmuseum,

Amsterdam KIT Publishers.

[6] Herman Ivo dalam Jurnal Humaniora Volume XIII, No 3/2001

[7] Harun, H. (2005). Sari Sejarah Filsafat Barat 2. Yoyakarta: Kanisius.

[8] Bagus, L. (2005). Kamus Filsafat. Jakarta: Gramedia Pustaka Utama

[9] Sugiyono. (2017). Metode Penelitian Pendidikan, Pendekatan Kuantitatif, Kualitatif dan $R \& D$. Bandung: Alfabeta.

[10] Pusat Bahasa. (2008). Kamus Bahasa Indonesia. Jakarta: Pusat Bahasa Departemen Pendidikan Bahasa. 